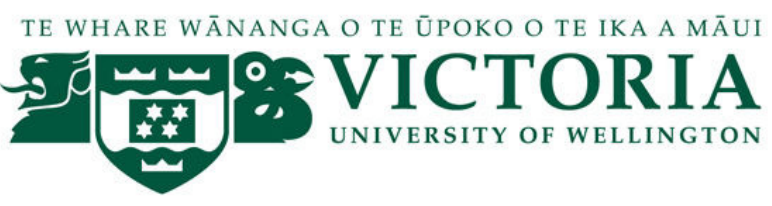

Faculty of Law

Victoria University of Wellington

\title{
Third State Intervention before the International Court of Justice in International Environmental Law Cases
}

\author{
LLM Seminar Paper \\ International Environmental Law (LAWS 530)
}

Franziska Liebelt 


\section{Contents}

I INTRODUCTION.................................................................................................... 3

II THE SYSTEM OF INTERVENTION BEFORE THE INTERNATIONAL COURT OF JUSTICE........................................................................................ 4

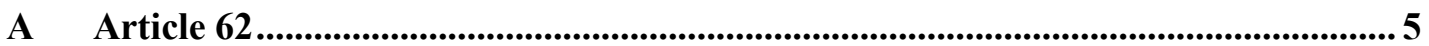

B Article 63 .......................................................................................................................... 6

C The Status of the Intervening State ........................................................................ 7

III THE CASE LAW ON INTERVENTION............................................................ 8

IV INTERESTS INVOLVED IN THIRD STATE INTERVENTION........................9

1 The intervening state ....................................................................................... 10

$2 \quad$ The parties of the dispute..................................................................................... 10

3 The court ...................................................................................................... 10

$4 \quad$ The international community ......................................................................... 11

V INTERVENTION IN ENVIRONMENTAL LAW CASES .................................... 11

A The Nuclear Tests Litigation............................................................................................ 12

$1 \quad$ Background to the litigation ......................................................................... 12

$2 \quad$ Analysis of the applications to intervene .................................................... 14

B Whaling in the Antaretic ............................................................................................ 16

$1 \quad$ Introduction to the case................................................................................ 16

2 General issues concerning intervention ........................................................ 16

$3 \quad$ Equality of the parties ...................................................................................... 17

$4 \quad$ Party autonomy $\mathrm{v}$ community interest ......................................................... 19

C Implications ...................................................................................................................... 21

VI INTEREST OF THE INTERNATIONAL COMMUNITY AND THE ROLE OF THE INTERNATIONAL COURT OF JUSTICE............................................... 22

A Erga Omnes Obligations to Protect the Environment............................................... 22

B The Role of the ICJ............................................................................................... 25

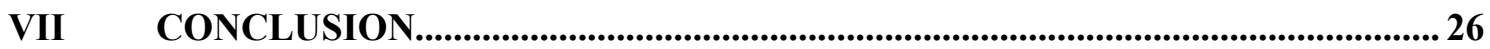

BIBLIOGRAPHY ..................................................................................................................... 28

The text of this paper (excluding footnotes, table of contents, headings and bibliography) comprises approximately 7500 words. 


\section{Introduction}

Third state intervention before international institutions originated in international arbitration around $1875^{1}$ and has been included in the statute of the International Court since the foundation of the Permanent Court of International Justice ${ }^{2}$ (PCIJ) and is therefore no new phenomenon. Today, most systems of international dispute settlement provide for the possibility of third state intervention. ${ }^{3}$ Nevertheless intervention before the International Court of Justice (ICJ) has been used by states sparsely and seems underdeveloped. ${ }^{4}$ The statute of the ICJ ${ }^{5}$ provides for two ways of intervention in its arts 62 and 63. There have been few applications under these provisions. Looking at the court's orders in these few cases, the court seems to have adopted a restrictive approach towards allowing applications to intervene. ${ }^{6}$

This paper looks at the institution of intervention in the area of international environmental law disputes. There have been two relevant disputes of this kind before the ICJ: the Nuclear Tests ${ }^{7}$ litigation and the recent litigation of Whaling in the Antarctic. ${ }^{8}$ Both of these cases dealt with the question of state obligations towards the protection of the environment. The applications to intervene in Nuclear Tests failed for reasons that will be explained in more detail below. New Zealand's application to intervene in Whaling in the Antarctic was authorized by the ICJ on the 6 February 2013 under art 63

1 C M Chinkin "Article 63" in Andreas Zimmermann (ed) (2ed) The Statute of the International Court of Justice. A Commentary (Oxford University Press, Oxford, 2012) 1573 at 1575.

2 Chinkin "Article 62" in Andreas Zimmermann (ed) (2ed) The Statute of the International Court of Justice. A Commentary (Oxford University Press, Oxford, 2012) 1529 at 1532.

3 Rüdiger Wolfrum "Intervention in the Proceedings before the International Court of Justice and the International Tribunal for the Law of the Sea" in P Chandrasekhara Rao and Rahmatullah Khan The International Tribunal for the Law of the Sea (Kluwer Law International, The Hague, 2001) 161 at 161; see for example the Understanding on Rules and Procedures Governing the Settlement of Disputes (DSU) (Marrakesh, 1994), art 10(2); the Statute of the International Tribunal for the Law of the Sea, United Nations Convention on the Law of the Sea (Montego Bay, 1982), arts 31 and 32 and the Convention on the Pacific Settlement of International Disputes (the Hague, 1907), art 84.

4 Wolfrum, above $\mathrm{n} 3$, at 161.

5 Statute of the International Court of Justice 1945

6 Boleslaw A Boczek International Law. A Dictionary (The Scarecrow Press, Lanham, Maryland (USA), 2005) at [311]; Wolfrum, above $\mathrm{n} 3$, at 161.

7 Nuclear Tests (Australia v France) (Judgment) [1974] ICJ Rep 253; Nuclear Tests (New Zealand v France) (Judgment) [1974] ICJ Rep 457 and Request for an Examination of the Situation in Accordance with Paragraph 63 of the Court's Judgment of 20 December 1974 in the Nuclear Tests (New Zealand v. France) Case (Order) [1995] ICJ Rep 288.

8 Whaling in the Antarctic (Australia v Japan) (2010), case pending. All filed documents and orders available on http://www.icj-cij.org/docket/index.php?p1=3\&p2=3\&k=64\&case=148\&code=aj. 
of the Statute of the ICJ. ${ }^{9}$ The case is exceptional in that it is only the second time the ICJ allowed intervention under art $63 .^{10}$

Both cases demonstrate that there are environmental issues that concern more than only the nations that are parties to the dispute. They indicate that intervention plays a particularly strong role in environmental issues because these issues by their nature often affect more than just two states. This paper analyses how the shared environmental concern of the international community might lead to an extension of intervention before the ICJ. It further more looks at the issues that arose before the court in connection with the intervention in Whaling in the Antarctic and how these issues were dealt with.

\section{The System of Intervention before the International Court of Justice}

To analyse the interventions in Whaling in the Antarctic and Nuclear Tests a basic understanding of the system of intervention before the ICJ is necessary. The statute of the ICJ provides for two ways of intervention by third states under its arts 62 and 63 . These articles are accompanied by arts 81 to 86 of the Rules of the ICJ, ${ }^{11}$ which regulate the procedure for an application to intervene. Both types of intervention do not give rise to a new dispute with different parties but constitute incidental proceedings. ${ }^{12}$ Thus, intervention depends entirely on the existence of the "main" case; if the case is dismissed, the intervention is moot. ${ }^{13}$

There are some established problems in regards to both articles. These include the questions of whether a jurisdictional link is needed for intervention, whether the intervening state is bound by the judgment in the case and whether the intervention is subject to the discretion of the court. It is not the object of this paper to comprehensively analyse these questions. It will only summarise the practice of the court in regards to these questions and later on explain how these practices might influence the intervention in environmental issues.

\footnotetext{
$9 \quad$ Statute of the International Court of Justice (1945), art 63.

10 Whaling in the Antarctic (Australia v Japan) (Separate Opinion of Judge Cancado Trindade) (2010) at [64].

11 Rules of Court (1978).

12 Haya de la Torre (Colombia v Peru) (judgment) [1951] ICJ Rep 71 at 76 and Chinkin, above n 1, at 1574.

13 Chinkin, above n 2, at 1533.
} 


\section{A Article 62}

Article 62 reads: ${ }^{14}$

1. Should a state consider that it has an interest of a legal nature which may be affected by the decision in the case, it may submit a request to the Court to be permitted to intervene.

2. It shall be for the Court to decide upon this request.

According to section 2 it lies in the discretion of the court to allow or deny the request to intervene. Article 62 does therefore not constitute a "right to intervention". ${ }^{15}$ However, the ICJ has stated that it has no discretion to deny the request solely on policy grounds. ${ }^{16}$ It has been a controversial question whether a jurisdictional link is needed to intervene under art 62. Against the requirement of such a link speaks that art 62 makes no reference to art 36 (as contrasted with for example art 53). ${ }^{17}$ Furthermore the fact that the intervention lies in the discretion of the court and does not depend on the decision of the parties suggests that no jurisdictional link is needed. ${ }^{18}$ This approach has been endorsed by the ICJ. ${ }^{19}$ It stated that intervention "is to ensure that a State with possibly affected interests may be permitted to intervene even though there is no jurisdictional link and it therefore cannot become a party." ${ }^{20}$ It founded its conclusion on the fact that the parties had agreed to the application of the Rules of the ICJ and therefore agreed to the possibility of third state intervention. ${ }^{21}$

Regarding the issue whether an intervening state is bound by the decision of the court, the court has taken the position that art 59 Statute ICJ ${ }^{22}$ protects an intervening party from

14 Statute of the International Court of Justice, art 62.

15 Fitzmaurice "The Law and Procedure of the International Court of Justice 1952-54: Questions of Jurisdiction, Competence and Procedure" (1958) 34 BYIL 1 at 127.

16 Continental Shelf (Tunisia v Libyan Arab Jamahiriya) (Judgment on Application to Intervene) [1981] ICJ Rep 3 at [17].

17 Christine Chinkin "Third Parties in International Law" (Clarendon Press, Oxford, 1993) at 152 and Chinkin, above $\mathrm{n} 2$, at 1558 .

18 Chinkin, above $\mathrm{n}$ 17, at 152.

19 Chinkin, above $\mathrm{n} 2$, at 1560 and 1561.

20 Land and Maritime Boundary between Cameroon and Nigeria (Cameroon v Nigeria) (Order on Application by Equatorial Guinea for Permission to Intervene) [1999] ICJ Rep 1029 at [15].

21 Wolfrum, above $\mathrm{n} 3$, at 169.

22 Statute of the International Court of Justice, art 59: "The decision of the Court has no binding force except between the parties and in respect of that particular case.". 
such an affect. ${ }^{23}$ However, it has been argued that the right to intervene came with the corresponding commitment of being bound by the decision, at least as far as the judgment relates to the intervention. ${ }^{24}$

Under art 62 the intervening party must show that it has an "interest of legal nature which may be affected by the decision in the case". This excludes any interests of purely political, economic or sociological nature. ${ }^{25}$ However, the exact meaning of "interest of legal nature" and whether it requires the breach of a legal right is unclear. ${ }^{26}$ Although the language of art 62 is very liberal the ICJ has taken a restrictive approach to its interpretation. $^{27}$ The court has stated that it is not enough for a third party to have a general interest in the principles of law that might be stated in the judgment. ${ }^{28}$ Instead, it is necessary for the intervening state to have an interest that may be affected "in its content and scope, by the court's future decision in the main proceedings." 29 The legal interest must be "the object of a real and concrete claim of that State, based on law, as opposed to a claim of a purely political, economic or strategic nature." ${ }^{30}$ An interest of a legal nature has been accepted in cases that concerned the rights to waterways that were shared by more than two nations. ${ }^{31}$

\section{$B$ Article 63}

Article 63 stipulates:

23 Land, Island and Maritime Frontier Dispute (El Salvador v Honduras) (Judgment on the Application by Nicaragua for Permission to Intervene) [1990] ICJ Rep 92 at [421]-[423] and Chester Brown "Article 59" in Andreas Zimmermann (ed) (2ed) The Statute of the International Court of Justice. A Commentary (Oxford University Press, Oxford, 2012) 1416 at 1440.

24 Chinkin, above $\mathrm{n} 2$, at 1564.

25 Fitzmaurice, above n 15, at 126 and Wolfrum, above n 3, at 165.

26 Wolfrum, above n 3, at 165 and Fitzmaurice, above n 15, at 126 and 127.

27 Chinkin, above $\mathrm{n} 2$, at 1546.

28 Sovereignty over Pulau Ligitan and Pulau Sipadan (Indonesia v Malaysia) (Judgment on the Application by the Philippines for Permission to Intervene) [2001] ICJ Rep 575 at [83]; Wolfrum, above n 3, at 168 and Yuji Iwasawa "WTO Dispute Settlement as Judicial Supervision" (2002) Journal of International Economic Law 287 at 301.

29 Territorial and Maritime Dispute (Nicaragua v Colombia) (Judgment on the Application by Honduras for Permission to Intervene) [2001] ICJ Rep 348 at [26] and Chinkin, above n 2, at 1551

30 Territorial and Maritime Dispute, above n 29, at [26].

31 Chinkin, above n 2, at 1548 and 1549; Land, Island and Maritime Frontier Dispute, above n 23 and Land and Maritime Boundary between Cameroon and Nigeria, above n 20. 
1. Whenever the construction of a convention to which states other than those concerned in the case are parties is in question, the Registrar shall notify all such states forthwith.

2. Every state so notified has the right to intervene in the proceedings; but if it uses this right, the construction given by the judgment will be equally binding upon it.

Compared to art 62, intervention under art 63(2) does not require the proof of a legal interest by the intervening state. The policy behind art 63 is that all parties to a treaty have an interest in its construction. They should therefore have the possibility to present their opinion on the issue of interpretation before the court makes its decision. ${ }^{32}$ All that is needed for an intervention under art 63 is that the intervening state is a party to the convention which is interpreted in the case and that the intervention relates to the construction of the convention. ${ }^{33}$ The required link between the intervener and the parties of the dispute is the treaty at issue. ${ }^{34}$ Article 63 is therefore only applicable to cases that concern the construction of a convention. In these cases art 63 stipulates that all parties to that convention have to be notified of the proceedings. Every state that was notified, so every state that is a party to the convention, has a right to intervene. According to art 63(2), if the third state uses this right, the construction given by the judgment will be equally binding for the third state, which constitutes an exception to art $59 .{ }^{35}$

\section{$C$ The Status of the Intervening State}

The exact status of the intervening state in the proceedings is still a point of uncertainty. ${ }^{36}$ The ground rules are set out in the Rules of the ICJ. Articles 85 and 86 of these rules stipulate that an intervening state shall be supplied with all the written documents so far filed in the proceedings and that it is entitled to submit a written statement within a set period of time as well as to participate in the oral proceedings. However, this does not determine the position of the intervening state in relation to the party states. In Land,

32 Chinkin, above $\mathrm{n} 1$, at 1597.

33 Whaling in the Antarctic (Australia v Japan) (Order on Declaration of Intervention of New Zealand) at [8].

34 Chinkin, above n 1, at 1590; Chinkin, above n 17, at 180 and Shigeru Oda "Intervention in the International Court of Justice. Articles 62 and 63 of the Statute" in Rudolf Bernhardt and others (eds) Völkerrecht als Rechtsordnung. Internationale Gerichtsbarkeit. Menschenrecht. Festschrift für Hermann Mosler (Springer-Verlagn, Berlin, 1983) 629 at 644.

35 Statute of the International Court of Justice, art 59: "The decision of the Court has no binding force except between the parties and in respect of that particular case."

36 Chinkin, above $\mathrm{n} 2$, at 1562. 
Island and Maritime Frontier Dispute, the court, allowing an application under art 62 for the first time, stated that: ${ }^{37}$

It is therefore clear that a State which is allowed to intervene in a case, does not, by reason only of being the intervener, become also a party to the case.

This conclusion was based on the principle of consensual jurisdiction. The argument was that, if a third state would be allowed to be a party merely by intervening, this would bypass the agreement of the parties necessary for the jurisdiction of the ICJ ${ }^{38}$ Only if the parties to the dispute gave their consent could the intervening state become an additional party. ${ }^{39}$ It is common ground by now, that the intervener does not become a party to the proceedings. ${ }^{40}$ However, this position has been criticised for reducing the position of an intervener close to that of an amicus curiae. ${ }^{41}$ This might be more problematic in the case of art 63, considering that under this provision, the intervener is bound by the outcome of the decision.

There are a couple of main differences between the status of an intervening party and the status of a third party to the proceedings. As mentioned above, no jurisdictional link is needed to intervene into proceedings, while a third state can only become a third party with the consent of the parties to the dispute. ${ }^{42}$ Furthermore, an intervening state is not bound by the decision under art 62 and only bound in regards to the construction of the treaty under art 63. Lastly, an intervening state has fewer procedural rights in the proceedings than the actual parties. ${ }^{43}$

\section{The Case Law on Intervention}

There have only been few interventions by third states before the International Court. One application was made before the $\mathrm{PCIJ}^{44}$ and 13 applications ${ }^{45}$ have been made to the

37 Land, Island and Maritime Frontier Dispute, above n 31, at [99].

38 Land, Island and Maritime Frontier Dispute, above n 31, at [99].

39 Land, Island and Maritime Frontier Dispute, above n 31, at [99].

40 Wolfrum, above $\mathrm{n} 3$, at 167 and Chinkin, above $\mathrm{n}$ 1, at 1591.

41 Wolfrum, above $\mathrm{n} 3$, at 169.

42 Chinkin, above $\mathrm{n} 2$, at 1561.

43 Chinkin, above $\mathrm{n} 2$, at 1563 and 1566.

44 SS Wimbledon (U.K. v. Japan) (Question of Intervention by Poland) (1923) PCIJ (ser A) No 1.

45 Haya de la Torre, above n 12, Cuba intervening; Nuclear Tests (Australia v France) (Application for Permission to Intervene Submitted by the Government of Fiji) [1973] ICJ Rep 320; Nuclear Tests (New Zealand v France) (Application by Fiji for Permission to Intervene) [1974] ICJ Rep 530; Continental Shelf (Tunisia $v$ Libyan Arab Jamahiriya) (Judgment on Application to Intervene) [1981] ICJ Rep 3; 
ICJ. The procedure of intervention has therefore only been used scarcely. ${ }^{46}$ Even more scarcely has the ICJ allowed applications to intervene. Of all the applications made before the ICJ only five applications were granted, including the application of New Zealand in Whaling in the Antarctic. ${ }^{47}$ Three of these were under art $62^{48}$ and two of these were under art $63 .{ }^{49}$ It can therefore be said that the ICJ has a rather narrow approach to third state intervention and has been restrained in allowing intervention. ${ }^{50}$ Therefore: ${ }^{51}$

What might well have been expected, at the time the Court's Statute was adopted, to grow into a substantial branch of international jurisprudence, has thus turned out to be extremely limited in its growth.

\section{Interests Involved in Third State Intervention}

Apart from the technicalities of intervention before the ICJ it is important to understand the underlying policies of intervention. This section therefore looks at the interests of the parties involved.

Continental Shelf (Libyan Arab Jamahiriya v Malta) (Application to Intervene) [1984] ICJ Rep 3; Military and Paramilitary Activities in and against Nicaragua (Nicaragua v United States of America) (Declaration of Intervention) [1984] ICJ Rep 215; Land, Island and Maritime Frontier Dispute, above, n 23; Land and Maritime Boundary between Cameroon and Nigeria (Cameroon v Nigeria) (judgment) [1996] ICJ Rep 13; Request for an examination of the situation in accordance with paragraph 63 of the Court's Judgment of 20 December 1974 in Nuclear Tests (New Zealand v France) (Application for Permission to Intervene by the Government of Australia) [1995] ICJ Rep 288; Sovereignty over Pulau Ligitan and Pulau Sipadan, above n 28, Philippines intervening; Territorial and Maritime Dispute, above n 29; Jurisdictional Immunities of the States (Germany v Italy) (Order on Application by Greece for Permission to Intervene) [2011] ICJ Rep 494 and Whaling in the Antarctic (Australia v Japan) (Declaration of Intervention of New Zealand) not yet in reports but available online at http://www.icjcij.org/docket/index.php?p1 $=3 \& \mathrm{p} 2=3 \& \mathrm{k}=64 \&$ case $=148 \&$ code $=a j \& \mathrm{p} 3=8$.

46 Chinkin, above $\mathrm{n}$ 2, at 1537 and Whaling in the Antarctic, above n 10, at [40].

47 Other applications were granted in: Haya de la Torre, above n 12, to Cuba; Land, Island and Maritime Frontier Dispute, above n 23 to Nicaragua; Land and Maritime Boundary between Cameroon and Nigeria, above n 20, to Equatorial Guinea and Jurisdictional Immunities of the States, above n 45, to Greece.

48 Land, Island and Maritime Frontier Dispute, above n 23; Land and Maritime Boundary between Cameroon and Nigeria, above n 20 and Jurisdictional Immunities of the States, above n 45.

49 Haya de la Torre, above $\mathrm{n} 12$ and Whaling in the Antarctic, above $\mathrm{n} 45$.

50 Wolfrum, above n 3, at 161 and Boczek, above n 6, at [311].

51 Sovereignty over Pulau Ligitan and Pulau Sipadan (Indonesia v Malaysia) (Separate Opinion of Judge Weeramantry) [2001] ICJ Rep 630 at [4]. 


\section{The intervening state}

First of all, the intervening state has interests that cause it to file the application to intervene before the ICJ. These interests vary between arts 62 and 63. Under art 62 the intervening state thinks that the decision in the proceedings might affect one if its rights and that it should therefore have the possibility to present its interests. Under art 63 the intervening state is a party to the convention in question and wants to contribute its opinion about an issue of interpretation of that convention. Typically the interpretation of a treaty lies in the interest of all its parties. They therefore want to present their own opinion on the matter before the court decides on a mode of interpretation.

However, not many states have used their right to intervene. This might be due to a number of reasons. First of all the intervention procedure causes the intervening state expenses it might not want to or might not be able to make. Furthermore there might be political interests involved that deter a state from intervening. International relationships might be at stake that an intervention would harm. Looking at the case of Whaling in the Antarctic, New Zealand relationship to Australia might have been negatively influenced if Australia had lost its ad hoc judge due to New Zealand's intervention. ${ }^{52}$ Lastly states might be deterred to intervene under art 63 because they do not want to be bound by the ICJ's decision.

\section{The parties of the dispute}

The parties of the running dispute might have different interests concerning the intervention of the third state. On one hand third state intervention might contradict the concept of party autonomy in international adjudication. ${ }^{53}$ The parties to the dispute might see the intervention as an unwanted interference that disturbs the peaceful settlement of their dispute. ${ }^{54}$ On the other hand, if the third state enters the proceedings to support the interest of one of the parties to the dispute, that party will most likely be in favour of the intervention. In this case the opposing party might feel like its position is considerably weakened and it might question the equality of the parties.

\section{The court}

The ICJ itself has an interest in allowing interventions. Firstly, intervention prevents further cases in the same issue that lead to repetitive litigation and possibly confusing or

\footnotetext{
52 See in more detail below at VB.

53 Chinkin, above n 2, at 1572.

54 Wolfrum, above n 3, at 162.
} 
even contradictory outcomes. ${ }^{55}$ Secondly the intervention by a third state will provide the court with further information that might be needed to render a just judgment. ${ }^{56}$ In some cases, where the dispute between the parties before the court affects the rights of a third state directly, intervention is desirable to enable a comprehensive legal settlement between all the affected parties. ${ }^{57}$ If the rights of the third state are not only affected but constitute the very subject matter of the case, the court might not even be able to decide that case without the intervention of that third state. ${ }^{58}$ These interests were emphasised in decisions in which the court made notice that an intervention would have been helpful, where no application for intervention had been made. ${ }^{59}$

\section{The international community}

Lastly, the international community might have an interest in intervention when the substance of the case is not limited to a dispute between the two parties before the court, but affects the international community as a whole. This is often the case, as international disputes rarely fit into a bilateral pattern. ${ }^{60}$ Particularly in environmental law it can be argued that most disputes have an impact on the entire international community and not just the two states directly involved. This is due to the fact that effects on the environment are often not limited to one country. Especially problems concerning pollution or migrating species are not subject to geographical borders. In these cases the international community has an interest to participate in the outcome of the decision to influence the development of international law. ${ }^{61}$

\section{$V$ Intervention in Environmental Law Cases}

Having laid out the background of third state intervention an analysis of two environmental cases where third states intervened will be conducted.

55 Sovereignty over Pulau Ligitan and Pulau Sipadan (Indonesia v Malaysia) (Separate Opinion of Judge Weeramantry) [2001] ICJ Rep 630 at [17]; Wolfrum, above n 3, at 161 and C M Chinkin "Third Party Intervention before the International Court of Justice" (1986) 80 Am J Int'l L 495 at 500.

56 Wolfrum, above $\mathrm{n} 3$, at 161.

57 Chinkin, above $\mathrm{n}$ 2, at 1536 and 1537.

58 Chinkin, above n 2, at 1536 and 1537 and Monetary Gold removed from Rome in 1943 (Italy v France, United Kingdom and United States) [1954] ICJ Rep 19 at 32.

59 Barcelona Traction, Light and Power Company, Limited (Belgium v Spain) (Judgment stage 2) (Separate Opinion Judge Fitzmaurice) [1970] ICJ Rep 65 at [28] and Chinkin, above n 2, at 1636.

60 Wolfrum, above $\mathrm{n} 3$, at 161.

${ }^{61}$ Chinkin, above $\mathrm{n} 2$, at 1572. 


\section{A The Nuclear Tests Litigation}

\section{Background to the litigation}

The first environmental issue before the ICJ that brought about third state intervention was the litigation concerning atmospheric nuclear tests France was conducting in the South Pacific Ocean. Two cases were brought before the ICJ in 1973 by Australia and New Zealand in separate claims. ${ }^{62}$ Australia alleged that the atmospheric nuclear tests were not consistent with international law and asked the court to order that "the French republic shall not carry out any further such tests." ${ }^{{ }^{63}}$ Australia asserted that the nuclear tests had caused nuclear fallout on Australian territory. ${ }^{64}$ New Zealand extended the argument of nuclear fallout on its own territory by alleging a broad consensus of the international community that nuclear weapons and nuclear tests were condemned ${ }^{65}$ It suggested that this consensus let to a "character erga omnes of the prohibition in this rule." ${ }^{66}$ This line of argumentation was later joined by Australia. ${ }^{67}$

Fiji filed applications to intervene under art 62 in both of these proceedings. ${ }^{68}$ The applications concentrated on the factual impact the nuclear testing had on their environment. ${ }^{69}$ They did not include elaborations on the requirement of a legal interest as required by art 62 .

The court found that Australia's and New Zealand's objectives had already been fulfilled because the French government had stated publicly that it would conduct no further atmospheric nuclear tests. ${ }^{70}$ It therefore ruled that the claims no longer had an object and

$62 \quad$ Nuclear Tests (Australia v France) above $\mathrm{n} 7$ and Nuclear Tests (New Zealand v France), above $\mathrm{n} 7$.

63 Nuclear Tests (Australia v France) above n 7, at [11].

64 Nuclear Tests (Australia v France) above n 7, at [18].

65 Nuclear Tests (New Zealand v France) (Application instituting proceedings) ICJ Pleadings Nuclear Tests II at [23], [24] and [28].

66 Maurizio Ragazzi The Concept of International Obligations Erga Omnes (Clarendon Press Oxford, Oxford, 1997) at 177.

67 Ragazzi, above n 66, at 175 and 176.

68 Nuclear Tests (Australia v France) (Judgment), above n 7, at [7].

69 Nuclear Tests (Australia v France), above n 45, at 149 to 151 and Nuclear Tests (New Zealand v France), above n 45, at 89 to 91.

70 Nuclear Tests (Australia v France), above n 7, at [52] and Nuclear Tests (New Zealand v France), above $\mathrm{n} 7$, at [55]. 
the court could not fall a decision in the case. ${ }^{71}$ As a result, the incidental proceedings lapsed and no substantial comments were made on the matter of intervention. ${ }^{72}$

In 1995 New Zealand filed an application to examine the situation of the judgment rendered by the ICJ in $1974 .^{73}$ This application was based on underground nuclear tests that France had been conducting since the 1974 case. ${ }^{74}$ New Zealand alleged that these tests had a detrimental effect on the marine environment. ${ }^{75}$ It alleged that the court had wrongfully limited New Zealand's former application to atmospheric nuclear testing and asked the ICJ to examine the case anew in the light of the underground tests. ${ }^{76} \mathrm{New}$ Zealand contended that the nuclear tests violated provisions of the Noumea Convention ${ }^{77}$ and of customary international law. Australia filed an application to intervene along with Samoa, Micronesia, the Marshall Islands and the Solomon Islands.

The court dismissed New Zealand's application because in its view the basis of the 1974 judgement was not affected. ${ }^{78}$ The court ruled that the original litigation had rightfully been limited to atmospheric tests and the court could therefore not take other nuclear tests into consideration. ${ }^{79}$ In its judgment the court did not address the interventions filed by the aforementioned countries. This was criticised by Sir Geoffrey Palmer, ad hoc judge in the proceedings: ${ }^{80}$

$71 \quad$ Nuclear Tests (Australia v France), above $\mathrm{n}$ 7, at [62] and Nuclear Tests (New Zealand v France), above $\mathrm{n} 7$, at [65].

72 Nuclear Tests (Australia v France) (Order on the Application by Fiji for permission to intervene) [1974] ICJ Rep 530 at 531 and Nuclear Tests (New Zealand v France) (Order on the Application by Fiji for permission to intervene) at 536.

73 Request for an Examination of the Situation in Accordance with Paragraph 63 of the Court's Judgment of 20 December 1974 in the Nuclear Tests (New Zealand v France) Case (Application instituting proceedings).

74 At [21].

75 At [24] to [55].

76 At [19] and [69].

77 Convention for the Protection of Natural Resources and Environment of the South Pacific Region (opened for signature 24 November 1986, entered into force 22 August 1990).

78 Request for an Examination of the Situation in Accordance with Paragraph 63 of the Court's Judgment of 20 December 1974 in the Nuclear Tests, above n 7, at [65].

79 Request for an Examination of the Situation in Accordance with Paragraph 63 of the Court's Judgment of 20 December 1974 in the Nuclear Tests, above n 7, at [59].

80 Request for an Examination of the Situation in Accordance with Paragraph 63 of the Court's Judgment of 20 December 1974 in the Nuclear Tests (New Zealand v France) Case (dissenting opinion of Sir Geoffrey Palmer) [1995] ICJ Rep 381 at [24]. 
... they [the countries that had filed an application to intervene] well may have been able to add valuable assistance to the Court's consideration.

\section{Analysis of the applications to intervene}

Because the interventions were not seriously considered by the ICJ in these cases, the cases do not give much implication on the impact of intervention in environmental law cases. However, the litigation shows that environmental issues often affect more than just the parties to the case and are therefore prone to cause intervention by the international community. This will be shown on the basis of the applications to intervene in the 1995 litigation.

Australia's application to intervene is limited to art 62. The application first summarises the claim as it had been phrased in the application for the proceedings by New Zealand. ${ }^{81}$ It summarises the rights that New Zealand had invoked and separates them into erga omnes and erga partes rights, in other words rights that concern the whole international community and rights that only exist between New Zealand and France. The erga omnes rights were essential for Australia's application to intervene, as they could build the basis for their legal interest as required by art 62 . New Zealand had invoked two rights that it attributed to the entire international community: ${ }^{82}$

(a) the right of all members of the international community, including New Zealand, that no nuclear tests that give rise to radioactive fallout be conducted and

(b) the right of all members of the international community, including New Zealand, to the preservation from unjustified artificial radioactive contamination of the terrestrial, maritime and aerial environment and, in particular, of the environment of the region in which the tests are conducted and in which New Zealand, the Cook Islands, Niue and the Tokelau Islands are situated.

Australia referred to the analysis conducted by New Zealand establishing that these rights were international rights shared by all nations. The following segments of New Zealand's submission summarise the foundational argument: ${ }^{83}$

$\overline{81}$ Request for an Examination of the Situation in Accordance with Paragraph 63 of the Court's Judgment of 20 December 1974 in the Nuclear Tests (New Zealand v. France) (Application for Permission to Intervene under the Terms of Article 62 of the Statute Submitted by the Government of Australia) at [11] to [17].

82 Request for an Examination of the Situation in Accordance with Paragraph 63 of the Court's Judgment of 20 December 1974 in the Nuclear Tests, above $\mathrm{n} 81$, at [13].

83 Request for an Examination of the Situation in Accordance with Paragraph 63 of the Court's Judgment of 20 December 1974 in the Nuclear Tests, above n 81, at [15] and [17]. 
The rights listed under (a) and (b) are shared in the sense that their violation in relation to any one nation will necessarily involve a violation of the same rights vested in other members of the international community. ... [These rights] reflect a community interest in the protection of the security, life and health of all peoples and in the preservation of the global environment.

Nuclear testing of the kind carried out by France inevitably produces results in areas beyond the limits of national jurisdictions. In that sense, and in a broader sense as well, the common heritage of mankind is affected.

Australia then inferred that, if these rights were in fact of such an international nature and constituted obligations France owed to the entire international community, which was up to the court to determine, Australia would be eligible to intervene and so would be any other nation in the world. ${ }^{84}$ It drew a comparison to an international treaty to which all, or almost all, countries of the world are parties, under which circumstances all of these countries would have the right to intervene according to art $63 .{ }^{85}$ In establishing a legal interest Australia concluded: ${ }^{86}$

However, while the dispute between New Zealand and France is bilateral, it remains the case that in determining the merits of the New Zealand claim, the court would necessarily be required to pronounce on the rights of all States. The legal interest of every member of the international community, even of those States not bound by the judgment, are thus "affected" or "en cause" within the meaning of Article 62 of the Statute.

The Solomon Islands, the Marshall Islands, Samoa and Micronesia applied for interventions under art 62 with a similar reasoning as Australia and additionally for intervention under art 63 based on their membership to the Noumea Convention. ${ }^{87}$ Their applications were identical. The Noumea Convention is a convention on the protection of

84 At [15], [18] and [19].

85 At [15] and [23].

86 At [20].

87 Convention for the Protection of Natural Resources and Environment of the South Pacific Region (opened for signature 24 November 1986, entered into force 22 August 1990) and Request for an Examination of the Situation in Accordance with Paragraph 63 of the Court's Judgment of 20 December 1974 in the Nuclear Tests (New Zealand v France) (Application for Permission to Intervene under Article 62. Declaration of Intervention under Article 63 submitted by the Government of Solomon Islands) at [27] to [40]. 
the environment in the South Pacific region to which both New Zealand and France are signatories. ${ }^{88}$ The Island states contended that the ICJ would have to consider the construction of the treaty, in particular the articles that demand for an environmental impact assessment and for particular caution with nuclear testing. ${ }^{89}$

\section{$B \quad$ Whaling in the Antarctic}

\section{Introduction to the case}

The most recent case of Whaling on the Antarctic is another example of third state intervention in international environmental disputes. On 31 May 2010 Australia filed an application to the ICJ for proceedings against Japan. In this application Australia alleged that Japan had breached its obligations under the International Convention for the Regulation of Whaling ${ }^{90}$ (the Convention) by conducting a whaling programme in the Antarctic. The merits of the case are not important for the topic of intervention, but in summary Australia contended that Japan had misused a provision of the Convention under which a state may allow whaling for scientific purposes to justify commercial whaling. On 20 November 2012 New Zealand filed an application to intervene into the proceedings under art 63(2) of the Statute of the ICJ. New Zealand's application was based on its status as a party to the Convention. The application was unanimously granted by the court by order from 6 February 2013 .

This section takes a closer look at the way that intervention was used in Whaling in the Antarctic as a further example of intervention in a case concerning environmental issues. It will analyse the issues that arose before the court and how they were dealt with. The intervention of New Zealand in Whaling in the Antarctic is particularly interesting in that it shows some of the difficulties that arise when a third state is allowed to intervene.

\section{General issues concerning intervention}

Unfortunately the declaration of the court allowing New Zealand's intervention is not particularly instructive with regards to the general issues concerning intervention. ${ }^{91}$ In the words of Judge Gaja: ${ }^{92}$

88 http://www.unep.org/regionalseas/programmes/nonunep/pacific/instruments/default.asp.

89 Convention for the Protection of Natural Resources and Environment of the South Pacific Region (opened for signature 24 November 1986, entered into force 22 August 1990), arts 16 and 12.

90 International Convention for the Regulation of Whaling 1946.

91 Whaling in the Antarctic, above n 33.

92 Whaling in the Antarctic (Australia v Japan) (Declaration of Judge Gaja). 
It may be regretted that the Court, facing for the first time in several decades a declaration of intervention under Article 63 of the Statute, has not seized the opportunity for clarifying certain aspects of the procedure relating to this type of intervention.

The court confirmed that art 63(2) gives the applicant a "right" to intervene and that the intervening state does not become a party to the proceedings. ${ }^{93}$ The court did not elaborate on any of the contested issues under art 63(2), such as what is needed for a request to relate to the construction of the convention.

However, some interesting aspects of the intervention can be drawn from New Zealand's application to intervene and Australia's and Japan's comments on the application. Furthermore the separate opinions filed by three of the judges include some interesting remarks. Particularly Judge Cançado Trindade used this opportunity to make some general observations of the institution of intervention before the ICJ. This section focuses on two issues that were addressed in these documents: the equality of the parties and the interest of the international community in the case.

\section{Equality of the parties}

Whereas Australia was content with the intervention of New Zealand, Japan's written observations on the application to intervene included some concerns in connection with the intervention. It drew the court's attention to "certain serious anomalies that would arise from the admission of New Zealand as an intervener." 94 Japan was concerned that the equality of the parties would no longer be ensured because Australia and New Zealand were pursuing a joint case. That concern was based partly on a joint media release by New Zealand and Australia, announcing that "both countries have agreed to work together towards the elimination of whaling in the Southern Ocean through complementary strategies." 95 Furthermore Australia had appointed a judge ad hoc under art 31(2) of the Statute of the ICJ. A New Zealand judge had already been on the Bench, so that in Japan's view the interests of those countries were overrepresented. ${ }^{96}$ Japan based this argument on art 31(5) of the Statute of the ICJ. Article 31 stipulates the rules on the representation of the nationality of the parties in form of a judge. The relevant subsections read:

93 Whaling in the Antarctic, above n 33, at [2], [3] and [7].

94 Whaling in the Antarctic, above n 33, at [17].

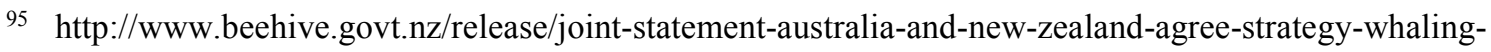
legal-case; Whaling in the Antarctic, above n 10, at [13].

96 Whaling in the Antarctic, above n 33, at [17]. 
1. Judges of the nationality of each of the parties shall retain their right to sit in the case before the Court.

2. If the Court includes upon the Bench a judge of the nationality of one of the parties, any other party may choose a person to sit as judge. Such person shall be chosen preferably from among candidates as provided in Articles 4 and 5 .

3. If the Court includes upon the Bench no judge of the nationality of the parties, each of these parties may proceed to choose a judge as provided in paragraph 2 of this Article.

5. Should there be several parties in the same interest, they shall, for the purpose of the preceding provisions, be reckoned as one party only. Any doubt upon this point shall be settled by the decision of the Court.

Based on subsection 5, Japan contended that Australia and New Zealand were "parties in the same interest" and should therefore not both have a judge of their nationality on the bench. Japan was furthermore of the opinion that the intervention under art 63(2) by New Zealand to join the case of Australia was "a strategy to avoid having to prove an interest of legal nature as required by art 62."97 Japan contended that the written and oral pleadings granted to New Zealand as an intervener would essentially amount to additional pleading by Australia, beyond the scope of the pleadings allowed to the parties by the court.

New Zealand answered Japan's concerns by stating that the equality of the parties could not be affected by the intervention of a non-party and that the right to intervene under art 63(2) was an integral part of the procedural framework of the ICJ. ${ }^{98}$ The ICJ seemed to agree with that argument. In its declaration on the intervention the court stated that, because intervention under art 63 of the Status of the ICJ was limited to "submitting observations on the construction of the convention" "99 "such an intervener cannot affect the equality of the parties to the dispute." 100 The court took the opinion that Australia and New Zealand could not be seen as being "parties in the same interest" and that therefore the ad hoc judge Australia had appointed could stay on the bench. ${ }^{101}$

97 Whaling in the Antarctic, above n 10, at [14].

98 Whaling in the Antarctic, above n 10, at [20].

99 Whaling in the Antarctic, above n 33, at [18].

100 Whaling in the Antarctic, above n 33, at [18].

101 At [21]. 
In his separate opinion Judge Owada, though agreeing with the decision of the court to allow New Zealand's intervention, underlined the concerns that Japan had about the intervention and that the court should have scrutinised these more closely. In his opinion it was up to the court to determine whether the intervention would keep in line with the principle of a fair trial and, in particular, preserve the equality of the parties in the proceedings. Judge Owada properly criticised the court's conclusion that a state that intervenes as non-party simply cannot affect the equality of the parties to the dispute as being "oversimplified". ${ }^{102}$

\section{Party autonomy $v$ community interest}

Under art 63 the required link between the intervener and the parties of the dispute is the treaty at issue. No further jurisdictional link is needed. ${ }^{103}$ Even though this seems to be the majority opinion, Judge Trindade dedicates two sections in his separate opinion to the question of whether or not the consent of the parties to the dispute should be obtained for the intervention of a third state. In this context he makes some very interesting remarks on the role of intervention in certain legal fields.

The judge first notes that party consent is not needed for third state intervention, because the ICJ is "master of its own jurisdiction". ${ }^{104} \mathrm{He}$ then takes that thought further to say that the nature of the treaty and the interest of the international community should be taken into account when deciding on the intervention of a third state. He emphasises the importance of third state intervention in cases where the treaty at issue "embod[ies] matters of collective interest, and [is] endowed with collective guarantee of the observance of the obligations contracted by the State Parties." ${ }^{105}$ He finds that the nature of the treaty and its execution are of particular importance in cases regarding the protection of matters of general interest: ${ }^{106}$

When it comes to protection (of human person, of the environment, or of matters of general interest), the principle of effet utile assume particular importance in the determination of the (enlarged) scope of the conventional obligations of protection.

102 Whaling in the Antarctic (Australia v Japan) (Declaration of Judge Owada) at [3].

${ }^{103}$ Chinkin, above n 1, at 1590; Chinkin, above n 17, at 180 and Shigeru Oda "Intervention in the International Court of Justice. Articles 62 and 63 of the Statute" in Rudolf Bernhardt and others (eds) Völkerrecht als Rechtsordnung. Internationale Gerichtsbarkeit. Menschenrecht. Festschrift für Hermann Mosler (Springer-Verlagn, Berlin, 1983) 629 at 644.

104 Whaling in the Antarctic, above n 10, at [22].

105 Whaling in the Antarctic, above n 10, at [53].

106 Whaling in the Antarctic, above n 10, at [55]. 
He also refers to a previous separate opinion he appended to the court's order in Jurisdictional Immunities of the State ${ }^{107}$, where he said that: ${ }^{108}$

Unlike land and maritime delimitation cases, or other cases concerning predominantly bilateralized issues, the present case is of interest to third States ... other than the two contending Parties before the Court. The subject-matter is closely related to the evolution of international law itself in our times, being of relevance, ultimately, to all States, to the international community as a whole, and, in my perception, pointing towards an evolution into a true universal international law.

Looking at the nature of the Treaty on the Regulation of Whaling he finds that the Treaty goes beyond bilateral relations of states and that this should be kept in mind when considering New Zealand's right to intervene. ${ }^{109}$

He sees the court's decision on the intervention in Whaling in the Antarctic as an indication of a more proactive posture towards intervention, which in his view: ${ }^{110}$

appears in principle justified, in cases like the present one, concerning the interpretation or construction of a provision of a multilateral treaty like the ICRW, aiming above all at the conservation of all whales species, to the benefit of future generations in all nations.

In summary Judge Trindade makes a case for third state intervention in decisions that, by their nature, do not only affect the two states before the court, but affect the whole international community. The perception of cases before the ICJ as "bilateral" was "a perception of the past" which did not reflect the development of international law today. ${ }^{111}$ This counted for example for decisions that concern the preservation of the environment. Judge Trindade sees intervention as of growing importance in the "evolution of contemporary international law as a truly universal international law."112

107 Jurisdictional Immunities of the States, above $\mathrm{n} 45$.

108 Jurisdictional Immunities of the States (Germany v Italy) (Separate Opinion of Judge Trindade) at [58].

109 Whaling in the Antarctic, above n 10, at [60].

110 Whaling in the Antarctic, above n 10, at [61].

111 Whaling in the Antarctic, above n 10, at [71].

112 Whaling in the Antarctic, above n 10, at [68]. 
The authorisation of New Zealand's intervention makes him sense a "revival" of the right to intervene before the ICJ: ${ }^{113}$

In the present case of Whaling in the Antarctic, the Court has adopted [an] Order granting the requested intervention in [a] domain of great importance in and for the development of contemporary international law, namely, that of marine life and resources and international protection of the environment. In the ambit of the circumstances surrounding [this] recent case, in [a] domain of concern to the international community as a whole, intervention has at least seen the light of the day.

\section{Implications}

Several implications can be drawn from the two cases analysed above. Both cases show that environmental issues attract the interest of third states. The Nuclear Tests litigation raises some interesting thoughts on the question whether environmental damage can give rise to a "legal interest" under art 62 , suggesting environmental issues affect the whole international community. Whaling in the Antarctic on the other hand also shows some of the difficulties that can arise through the intervention of third states.

Australia's and New Zealand's submissions in Nuclear Tests as well as Judge Trindade's separate opinion in Whaling in the Antarctic suggest that in any case where rights are concerned that are shared by the whole international community, every state in the world has a right to intervene. ${ }^{114}$ As the nations applying to intervene alleged, the environmental effect of nuclear tests "raise issues which are more than bilateral in character." fallouts are not limited to a specific area but can cause widespread damage and affect a large area comprising several nations' territories. They refer to Barcelona Traction, ${ }^{116}$ where the ICJ made statements about erga omnes obligations between all states. ${ }^{117}$ They develop the idea of erga omnes obligations where the environment is concerned and

${ }_{113}$ Whaling in the Antarctic, above n 10, at [64].

114 Request for an Examination of the Situation in Accordance with Paragraph 63 of the Court's Judgment of 20 December 1974 in the Nuclear Tests, above n 81, at [15] and [22].

${ }^{115}$ Request for an Examination of the Situation in Accordance with Paragraph 63 of the Court's Judgment of 20 December 1974 in the Nuclear Tests (New Zealand v. France) (Application for Permission to Intervene under Article 62. Declaration of Intervention under Article 63 submitted by the Government of Solomon Islands) at [4].

116 Barcelona Traction, Light and Power Company, Limited (Belgium v Spain) (Judgment stage 2) [1970] ICJ Rep 3.

117 Request for an Examination of the Situation in Accordance with Paragraph 63 of the Court's Judgment of 20 December 1974 in the Nuclear Tests, above n 81, at [16] and [17]. 
suggest that these obligations lead to an "interest of legal nature" of all states within the meaning of art 62 . The recognition of such obligations would lead to a major broadening of the right to intervene and might cause the concept of intervention to go overboard. It is questionable whether such a perception of the right to intervene is in line with the object and purpose of third state intervention and further, whether this interpretation is compatible with the role of the ICJ as an institution for dispute resolution between states. This problem is emphasised by the issue of inequality of the parties raised by Japan in Whaling in the Antarctic, which shows that the involvement of multiple states can cause considerable problems in the dispute resolution between two parties.

\section{Interest of the International Community and the Role of the International Court of Justice}

\section{A Erga Omnes Obligations to Protect the Environment}

The two cases above show that environmental cases are prone to attract the intervention of third states. Environmental issues, by nature, in most cases affect more than two parties and therefore have the interest of several nations. One way to look at this particular feature of environmental issues is through the concept of erga omnes obligations of states, as it was invoked by Australia and New Zealand in the Nuclear Tests litigation. The relation between erga omnes obligations and intervention is the following: if an erga omnes obligation to protect the environment or not to conduct certain actions that harm the environment existed, every time a country would violate this obligation, it would affect the whole international community. As a result, all nations might have an "interest of legal nature" in the matter as required by art 62 and therefore all nations would possibly have the right to intervene in proceedings brought against the violating state.

The concept of erga omnes obligations of states was created by the ICJ in Barcelona Traction. ${ }^{118}$ The Barcelona Traction, Light and Power Company was originally founded in Canada but owed by a majority of Belgian shareholders. It operated mainly in Spain. In Barcelona Traction Belgium brought a claim for damages allegedly inflicted on the company and its owners by the Spanish Government by actions contrary to

118 Barcelona Traction, Light and Power Company, Limited (Belgium v Spain), above n 116; Ragazzi, above $\mathrm{n} 66$, at 9 , clarifying that the concept predates the dictum of the ICJ. 
international. ${ }^{119}$ In its judgment, the court made mention of erga omnes obligations that states own to the entire international community: ${ }^{120}$

33. When a State admits into its territory foreign investments or foreign nationals, whether natural or juristic persons, it is bound to extend to them the protection of the law and assumes obligations concerning the treatment to be afforded them. These obligations, however, are neither absolute nor unqualified. In particular, an essential distinction should be drawn between the obligations of a State towards the international community as a whole, and those arising vis-à-vis another State in the field of diplomatic protection. By their very nature the former are the concern of all States. In view of the importance of the rights involved, all States can be held to have a legal interest in their protection; they are obligations erga omnes.

34. Such obligations derive, for example, in contemporary international law, from the outlawing of acts of aggression, and of genocide, as also from the principles and rules concerning the basic rights of the human person, including protection from slavery and racial discrimination. Some of the corresponding rights of protection have entered into the body of general international law (Reservations to the Convention on the Prevention and Punishment of the Crime of Genocide, Advisory Opinion, I.C.J. Reports 1951, p. 23); others are conferred by international instruments of a universal or quasi-universal character.

The concept of erga omnes obligations is nowadays widely accepted in the international practice, case law and literature. ${ }^{121}$ However, there is no universal definition of the concept and its applicability is only established in the particular areas of law that were mentioned by the ICJ in Barcelona Traction. ${ }^{122}$ To establish erga omnes obligations it is not necessary to prove that the norm has been recognised as jus cogens by the international community. ${ }^{123}$ Instead the ICJ stated that the nature of the particular obligation must be examined to ascertain whether the obligation is one erga omnes. This nature finds its basis in "the recognition of the universal validity of the basic moral values that these obligations are meant to protect." 124 The degree of evidence needed to prove

119 Barcelona Traction, Light and Power Company, Limited, above n 116, at [1], [8] and [9].

120 At [33] and [34].

121 Ragazzi, above $\mathrm{n} 66$, at 5 and 12 to 17.

122 Ragazzi, above n 66, at 183 and Stefan Kadelbach "Jus Cogens, Obligations Erga Omnes and other Rules - The Identification of Fundamental Norms in Christian Tomuschat and Jean-Marc Thouvenin (eds) The Fundamental Rules of the International Legal Order (Martinus Nijhoff Publishers, Leiden, 2006) 21 at 27.

123 Ragazzi, above n 66, at 182.

124 Ragazzi, above n 66, at 183. 
such a "nature" is uncertain. ${ }^{125}$ In their pleadings, Australia and New Zealand based an erga omnes obligation not to conduct nuclear testing on an alleged international consensus regarding the condemnation of nuclear testing. They based this allegation on several treaties restricting nuclear testing. ${ }^{126}$ They furthermore drew a comparison between the obligation they invoked and those obligations that had been accepted by the ICJ in Barcelona Traction. ${ }^{127}$ It is unfortunate that the ICJ did not pronounce on erga omnes obligations in Nuclear Tests. The separate opinions by the judges in the case show furthermore that it is unclear whether erga omnes obligations would automatically lead to a right to intervene. ${ }^{128}$

The question whether the condemnation of nuclear testing was and is accepted as an erga omnes obligation and whether such obligations lead to the right to intervene stays unanswered and cannot be resolved in this paper. ${ }^{129}$ For the purpose of the discussion of the role of intervention in international environmental cases it will be decisive whether, in future, the ICJ accepts erga omnes obligations concerning the protection of the environment. If such obligations were accepted, it is at least likely that an increasing number of states would be eligible to intervene in cases that concern environmental issues. Particularly issues regarding migrating species and the pollution of common elements, such as the oceans and the atmosphere, might open the floodgates for intervention by the entire international community. If one was to take the concept even further and include measures that contribute to the warming of the climate, intervention would take an extremely broad shape. This expansion of the right to intervene is enhanced by the fact that no jurisdictional link is needed to intervene under art 62. It is questionable whether such an understanding of intervention would be compatible with the role of the ICJ.

On the other hand the practice shows that at the current stage it is very unlikely that the number of intervening states will grow beyond control. As New Zealand and Australia

${ }^{125}$ Ragazzi, above $\mathrm{n} 66$, at 185.

${ }^{126}$ Ragazzi, above n 66, at 176.

127 Ragazzi, above n 66, at 178 and 179.

${ }^{128}$ Christian J Tams Enforcing Obligations Erga Omnes in International Law (Cambridge University Press, Cambridge, 2005) at 180 to 182.

${ }^{129}$ Malgosia Fitzmaurice "Environmental protection and the International Court of Justice" in Vaughan Lowe and Malgosia Firtzmaurice (eds) Fifty Years of the International Court of Justice (Cambridge University Press, Cambridge, 1996) 293 at 299 and 300. 
contended, usually only the states that have an immediate proximity to the environmental damage will make use of intervention. ${ }^{130}$

\section{$B$ The Role of the ICJ}

To address the question whether or not such a broad right to intervene would be compatible with the role of the ICJ it is necessary to analyse the ICJ's standing in the settlement of international conflicts.

The basis for this analysis is the fact that the jurisdiction of the ICJ is based and depends on the autonomy of the parties. The ICJ therefore has reason to be careful not to be too open towards third state intervention or it might deter recourse to the court. ${ }^{131}$ It can also be stated that disputes with multiple states before the ICJ are rare. Despite the fact that interests of multiple states are often involved, the parties usually present the dispute to the court as a bilateral dispute. ${ }^{132}$ One might say that " $[\mathrm{t}]$ he ICJ is best suited to deal with bilateral disputes of a traditional type."133 This position of the ICJ reflects the general tension imminent in the international adjudicative system in which the interest of the international community comes up against a system of bilateral dispute resolution. ${ }^{134}$

It is likely that the ICJ will be confronted with an increased amount of environmental claims and accordingly with an increased amount of applications to intervene. The court therefore has to "find a balance between not allowing third parties to intrude unnecessarily in litigation between other States, while not permitting States to ignore legitimate third party claims in their litigation." 135 In finding this balance it is desirable that the ICJ find a coherent approach towards third state intervention. This could be achieved by a clear statement about the existence of erga omnes rights in the environmental sphere and the development of a definition for the interest of legal nature under art $62 .{ }^{136}$

It is suggested that a more open attitude towards third state intervention in environmental law cases by the ICJ is desirable due to the global nature of environmental issues and that

${ }^{130}$ Request for an Examination of the Situation in Accordance with Paragraph 63 of the Court's Judgment of 20 December 1974 in the Nuclear Tests (New Zealand v. France), above n 81, at [22].

${ }^{131}$ Chinkin, above $\mathrm{n} 17$, at 149.

${ }^{132}$ Chinkin, above $\mathrm{n} 17$, at 148 .

${ }^{133}$ Iwasawa, above $\mathrm{n} 28$, at 299.

${ }^{134}$ Chinkin, above n 17, at 147 and 148 .

135 Chinkin, above n 17, at 149.

${ }^{136}$ Chinkin, above $\mathrm{n}$ 17, at 149. 
such an approach is also compatible with the role of the ICJ. Environmental claims are likely to increase in number and at the same time in scale. Even if the ICJ was originally designed for bilateral disputes, its function should grow with the challenges that develop from a change in the international community towards greater environmental concerns and obligations. In the author's opinion, the reluctance of states to file applications to intervene is for the time being a sufficient safeguard for over boarding interventions. However, the ICJ needs to maintain the equality of the parties in the proceedings. Whaling in the Antarctic showed that this can be difficult when the intervening state factually joints one of the parties to the dispute. In these cases the ICJ should take the necessary measures to keep a balance of powers by adequately restraining the rights of the intervening party.

\section{Conclusion}

International disputes can increasingly not be limited to the dispute between two parties, but often affect the whole international community. This can be said in particular for disputes concerning the environment shared by all nations. In the words of Tullio Scovazzi: ${ }^{137}$

Today, international environmental law is not limited to traditional instances of transboundary harm where a polluting substance crosses the border between two or more States. ... present international law must also address global risks which threaten the maintenance of equilibria indispensable for the survival of life on earth.

The growing concern about our environment shared by the international community might almost cause an obligation for states to intervene in international environmental cases to ensure that the interests of all affected parties are taken into account. The institution of intervention could serve as a means of reciprocal control between all states to ensure the protection of the environment. This effect would be inevitable if erga omnes obligations to protect the environment were to emerge. It is the opinion of this paper that a growing right of intervention is compatible with the role of the ICJ, because an international court should be able to adapt to the needs of the international community. One might question whether or not the ICJ is the right institution to decide environmental disputes, ${ }^{138}$ but if confronted with such a dispute, it should allow for intervention by the

137 Tullio Scovazzi "Some Remarks on International Responsibility in the Field of Environmental Protection" in Maurizio Ragazzi (ed) International Responsibility Today. Essays in Memory of Oscar Schachter (Martinus Nijhoff, Publishers, Leiden, 2005) 209 at 213.

${ }^{138}$ Fitzmaurice, above n 129, at 301. 
affected states. This is particularly important because there are currently no comprehensive schemes of state responsibility and compensation in the environmental context. ${ }^{139} \mathrm{~A}$ greater discourse about such obligations through the medium of intervention could help to develop adequate rules about the protection of the environment. As Judge Trindade observed, Whaling in the Antarctic might be the beginning of such an expanded policy towards intervention both by states and the ICJ.

${ }^{139}$ Scovazzi, above $\mathrm{n}$ 137, at 213. 


\section{Bibliography}

I Cases

A International Court of Justice

Barcelona Traction, Light and Power Company, Limited (Belgium v Spain) (Judgment stage 2) [1970] ICJ Rep 3.

Barcelona Traction, Light and Power Company, Limited (Belgium v Spain) (Judgment stage 2) (Separate Opinion Judge Fitzmaurice) [1970] ICJ Rep 65.

Continental Shelf (Libyan Arab Jamahiriya v Malta) (Application to Intervene) [1984] ICJ Rep 3.

Continental Shelf (Tunisia v Libyan Arab Jamahiriya) (Judgment on Application to Intervene) [1981] ICJ Rep 3.

Haya de la Torre (Colombia v Peru) (judgment) [1951] ICJ Rep 71.

Jurisdictional Immunities of the States (Germany v Italy) (Order on Application by Greece for Permission to Intervene) [2011] ICJ Rep 494.

Jurisdictional Immunities of the States (Germany v Italy) (Separate Opinion of Judge Trindade).

Land and Maritime Boundary between Cameroon and Nigeria (Cameroon v Nigeria) (Order on Application by Equatorial Guinea for Permission to Intervene) [1999] ICJ Rep 1029.

Land and Maritime Boundary between Cameroon and Nigeria (Cameroon v Nigeria) (judgment) [1996] ICJ Rep 13.

Land, Island and Maritime Frontier Dispute (El Salvador v Honduras) (Judgment on the Application by Nicaragua for Permission to Intervene) [1990] ICJ Rep 92.

Military and Paramilitary Activities in and against Nicaragua (Nicaragua $v$ United States of America) (Declaration of Intervention) [1984] ICJ Rep 215. 
Monetary Gold removed from Rome in 1943 (Italy v France, United Kingdom and United States) [1954] ICJ Rep 19.

Nuclear Tests (Australia v France) (Judgment) [1974] ICJ Rep 253.

Nuclear Tests (Australia v France) (Application for Permission to Intervene Submitted by the Government of Fiji) [1973] ICJ Rep 320.

Nuclear Tests (Australia v France) (Order on the Application by Fiji for permission to intervene) [1974] ICJ Rep 530

Nuclear Tests (New Zealand v France) (Judgment) [1974] ICJ Rep 457.

Nuclear Tests (New Zealand v France) (Application instituting proceedings) ICJ Pleadings Nuclear Tests II.

Nuclear Tests (New Zealand v France) (Application by Fiji for Permission to Intervene).

Request for an Examination of the Situation in Accordance with Paragraph 63 of the Court's Judgment of 20 December 1974 in the Nuclear Tests (New Zealand v. France) Case (Order) [1995] ICJ Rep 288.

Request for an Examination of the Situation in Accordance with Paragraph 63 of the Court's Judgment of 20 December 1974 in the Nuclear Tests (New Zealand v France) Case (Application instituting proceedings).

Request for an Examination of the Situation in Accordance with Paragraph 63 of the Court's Judgment of 20 December 1974 in the Nuclear Tests (New Zealand v. France) (Application for Permission to Intervene under the Terms of Article 62 of the Statute Submitted by the Government of Australia).

Request for an Examination of the Situation in Accordance with Paragraph 63 of the Court's Judgment of 20 December 1974 in the Nuclear Tests (New Zealand v France) (Application for Permission to Intervene under Article 62. Declaration of Intervention under Article 63 submitted by the Government of Solomon Islands).

Request for an Examination of the Situation in Accordance with Paragraph 63 of the 
Court's Judgment of 20 December 1974 in the Nuclear Tests (New Zealand v France) Case (dissenting opinion of Sir Geoffrey Palmer) [1995] ICJ Rep 381.

Sovereignty over Pulau Ligitan and Pulau Sipadan (Indonesia v Malaysia) (Judgment on the Application by the Philippines for Permission to Intervene) [2001] ICJ Rep 575.

Sovereignty over Pulau Ligitan and Pulau Sipadan (Indonesia v Malaysia) (Separate Opinion of Judge Weeramantry) [2001] ICJ Rep 630.

SS Wimbledon (U.K. v. Japan) (Question of Intervention by Poland) (1923) PCIJ (ser A) No 1.

Territorial and Maritime Dispute (Nicaragua v Colombia) (Judgment on the Application by Honduras for Permission to Intervene) [2001] ICJ Rep 348.

Whaling in the Antarctic (Australia $v$ Japan) (Declaration of Intervention of New Zealand) not yet in reports but available online at http://www.icjcij.org $/$ docket $/$ index.php?p1 $=3 \& \mathrm{p} 2=3 \& \mathrm{k}=64 \&$ case $=148 \&$ code $=a j \& \mathrm{p} 3=8$.

Whaling in the Antarctic (Australia v Japan) (Order on Declaration of Intervention of New Zealand).

Whaling in the Antarctic (Australia v Japan) (Declaration of Judge Gaja).

Whaling in the Antarctic (Australia v Japan) (Declaration of Judge Owada).

Whaling in the Antarctic (Australia v Japan) (Separate Opinion of Judge Cancado Trindade). 
II International Documents

Statute of the International Court of Justice 1945.

Rules of the International Court of Justice 1978.

The Understanding on Rules and Procedures Governing the Settlement of Disputes (DSU) (Marrakesh, 1994).

The Statute of the International Tribunal for the Law of the Sea, United Nations Convention on the Law of the Sea (Montego Bay, 1982).

The Convention on the Pacific Settlement of International Disputes (the Hague, 1907)

III Books and Chapters in Books

Rudolf Bernhardt and others (eds) Völkerrecht als Rechtsordnung. Internationale Gerichtsbarkeit. Menschenrecht. Festschrift für Hermann Mosler (Springer-Verlagn, Berlin, 1983).

Boleslaw A Boczek International Law. A Dictionary (The Scarecrow Press, Lanham, Maryland (USA), 2005).

Chester Brown "Article 59" in Andreas Zimmermann (ed) (2ed) The Statute of the International Court of Justice. A Commentary (Oxford University Press, Oxford, 2012) 1416 , at 1440 .

P Chandrasekhara Rao and Rahmatullah Khan The International Tribunal for the Law of the Sea (Kluwer Law International, The Hague, 2001).

Christine Chinkin “Third Parties in International Law” (Clarendon Press, Oxford, 1993).

C M Chinkin “Article 62" in Andreas Zimmermann (ed) (2ed) The Statute of the International Court of Justice. A Commentary (Oxford University Press, Oxford, 2012) 1529.

C M Chinkin “Article 63" in Andreas Zimmermann (ed) (2ed) The Statute of the International Court of Justice. A Commentary (Oxford University Press, Oxford, 2012) 
1573.

Taslim O Elias "The Limits of the Right of Intervention in a Case before the International Court of Justice" in Rudolf Bernhardt and others (eds) Völkerrecht als Rechtsordnung. Internationale Gerichtsbarkeit. Menschenrecht. Festschrift für Hermann Mosler (Springer-Verlagn, Berlin, 1983) 159.

Malgosia Fitzmaurice "Environmental protection and the International Court of Justice" in Vaughan Lowe and Malgosia Firtzmaurice (eds) Fifty Years of the International Court of Justice (Cambridge University Press, Cambridge, 1996) 293.

Eduardo Jiménez de Aréchaga "Intervention under Article 62 of the Statute of the International Court of Justice" in Rudolf Bernhardt and others (eds) Völkerrecht als Rechtsordnung. Internationale Gerichtsbarkeit. Menschenrecht. Festschrift für Hermann Mosler (Springer-Verlagn, Berlin, 1983) 453.

Stefan Kadelbach "Jus Cogens, Obligations Erga Omnes and other Rules - The Identification of Fundamental Norms in Christian Tomuschat and Jean-Marc Thouvenin (eds) The Fundamental Rules of the International Legal Order (Martinus Nijhoff Publishers, Leiden, 2006) 21.

Vaughan Lowe and Malgosia Firtzmaurice (eds) Fifty Years of the International Court of Justice (Cambridge University Press, Cambridge, 1996).

Shigeru Oda "Intervention in the International Court of Justice. Articles 62 and 63 of the Statute" in Rudolf Bernhardt and others (eds) Völkerrecht als Rechtsordnung. Internationale Gerichtsbarkeit. Menschenrecht. Festschrift für Hermann Mosler (Springer-Verlagn, Berlin, 1983) 629.

Maurizio Ragazzi The Concept of International Obligations Erga Omnes (Clarendon Press Oxford, Oxford, 1997).

Maurizio Ragazzi (ed) International Responsibility Today. Essays in Memory of Oscar Schachter (Martinus Nijhoff, Publishers, Leiden, 2005).

P Chandrasekhara Rao and Rahmatullah Khan The International Tribunal for the Law of the Sea (Kluwer Law International, The Hague, 2001). 
Shabtai Rosenne Intervention in the International Court of Justice (Martinus Nijhoff Publishers, Dordrecht (Netherlands), 1993).

Tullio Scovazzi "Some Remarks on International Responsibility in the Field of Environmental Protection" in Maurizio Ragazzi (ed) International Responsibility Today. Essays in Memory of Oscar Schachter (Martinus Nijhoff, Publishers, Leiden, 2005) 209.

Christian J Tams Enforcing Obligations Erga Omnes in International Law (Cambridge University Press, Cambridge, 2005).

Christian Tomuschat and Jean-Marc Thouvenin (eds) The Fundamental Rules of the International Legal Order (Martinus Nijhoff Publishers, Leiden, 2006).

Rüdiger Wolfrum "Intervention in the Proceedings before the International Court of Justice and the International Tribunal for the Law of the Sea" in P Chandrasekhara Rao and Rahmatullah Khan The International Tribunal for the Law of the Sea (Kluwer Law International, The Hague, 2001) 161.

Rüdiger Wolfrum "Interventions in Proceedings Before International Courts and Tribunals: To What Extent May Interventions Serve the Pursuance of Community Interest?" in Nerina Boschiero and others (eds) International Courts and the Development of International Law. Essays in Honour of Tullio Treves (Asser Press, the Hague, 2013).

Andreas Zimmermann (ed) (2ed) The Statute of the International Court of Justice. A Commentary (Oxford University Press, Oxford, 2012).

Journal Articles

C M Chinkin "Third Party Intervention before the International Court of Justice" (1986) 80 Am J Int'l L 495.

G Fitzmaurice "The Law and Procedure of the International Court of Justice 1952-54: Questions of Jurisdiction, Competence and Procedure” (1958) 34 BYIL 1.

D W Greig “Third Party Rights and Intervention Before the International Court” (1992) 
32 Va J Int'1 L 285.

Yuji Iwasawa "WTO Dispute Settlement as Judicial Supervision" (2002) Journal of International Economic Law 287.

Karin Oellers-Frahm "Überlegungen anlässlich der Zulassung der Intervention Nicuraguas im Streit zwischen El Salvador und Honduras" (1990) 50 ZaöRV 795. 